\title{
Revisiting letter transpositions within and across morphemic boundaries
}

\author{
Jon Andoni Duñabeitia • Manuel Perea • \\ Manuel Carreiras
}

(C) Psychonomic Society, Inc. 2014

\begin{abstract}
Early morphological decomposition of complex words has been supported by evidence showing that the magnitude of masked transposed-letter (TL) priming effects is greater for within-morpheme transpositions than for between-morpheme transpositions. However, these findings have lately been called into question, and a recent article by Sánchez-Gutiérrez and Rastle (Psychonomic Bulletin \& Review, 20, 988-996, 2013) suggested that the abovementioned interaction could have been the consequence of a false positive (i.e., a Type I error). Considering recent evidence showing that morpho-orthographic interactions are highly sensitive to individual differences in reading skills, we explored whether participants' averaged reading speeds were responsible for modulating the size of within- versus between-morpheme TL priming effects. A large-scale lexical decision experiment with a set of 420 suffixed Spanish words ( $N=80$ participants) was run using the masked-priming technique. The results revealed that individual differences modulated the magnitude of the masked TL priming effect between morphemes: Faster readers (but not slower readers) yielded greater TL priming for within- than for betweenmorpheme transpositions. The present data help reconcile previous divergent data by showing that faster readers
\end{abstract}

Electronic supplementary material The online version of this article (doi:10.3758/s13423-014-0609-2) contains supplementary material, which is available to authorized users.

J. A. Duñabeitia $(\bowtie) \cdot$ M. Perea $\cdot$ M. Carreiras

Basque Center on Cognition, Brain and Language (BCBL),

Paseo Mikeletegi 69, 2nd floor, 20009 Donostia, Spain

e-mail: j.dunabeitia@bcbl.eu

M. Perea

Universitat de València, Valencia, Spain

M. Carreiras

Ikerbasque, Basque Foundation for Science, Bilbao, Spain revealed a morpho-orthographic interaction, whereas slower readers may rely more on a morphological-processing strategy that is not sensitive to morpho-orthographic interactions.

Keywords Morphological decomposition · Transposed letters $\cdot$ Lexical access

How readers encode and process morphologically complex words has become a central issue in cognitive psychology, especially in research on visual-word recognition. Recognizing an isolated polymorphemic word involves a number of underlying processes: encoding of letter position/ identity, morphological segmentation, lexical retrieval of each morpheme, and whole-word semantic information retrieval. The precise manner and order in which these processes occur (or co-occur) is a matter of contention that is subject to empirical research (see Amenta \& Crepaldi, 2012, for a comprehensive review).

Most researchers in visual-word recognition agree that the recognition of derived words (e.g., violinist) is guided by early morpheme detection processes occurring before whole-word processing has finished (violin + ist; e.g., Pastizzo \& Feldman, 2002, 2004; Rastle, Davis, \& New, 2004; Taft \& Forster, 1975, 1976; see also Diependaele, Duñabeitia, Morris, \& Keuleers, 2011, for evidence from nonnative speakers). Empirical evidence in favor of this view has generally been obtained from masked-priming experiments, in which the processing of a briefly presented prime is posited to reveal early nonstrategic processes (see Diependaele, Morris, Serota, Bertrand, \& Grainger, 2013, for review). Consequently, most studies on derivational morphology have concluded that morphological decomposition occurs at a very early stage of visual-word recognition (see Lavric, Elchlepp, \& Rastle, 2012).

Thus, one relevant question is whether (some of) the processes of morphological decomposition co-occur with letter position coding at very early stages of visual-word recognition. 
Following this line of reasoning, Christianson, Johnson, and Rayner (2005), conducted a masked-priming experiment (Exp. 3) examining whether letter transpositions across affix boundaries (e.g., boasetr-BOASTER) differed from transpositions that crossed a pseudo-affix boundary in a naming task (e.g., blusetr-BLUSTER; note that blust is not an English stem, as -er is not a real suffix in bluster). Transposed-letter (TL) effects are prototypical orthographic effects associated with letter-position coding mechanisms (e.g., Perea \& Lupker, 2003; see Gomez, Ratcliff, \& Perea, 2008; Grainger \& Whitney, 2004, for theoretical implications). Christianson et al. found that "TL primes did not significantly differ from the orthographic controls" (p. 1334; in their case, one-letter substitution primes - e.g., boasler-BOASTER) in the set of truly suffixed words. That is, naming latencies for suffixed words preceded by a TL nonword prime that crossed the affix boundary were similar to latencies for suffixed words preceded by an orthographic control (both $t \mathrm{~s}<1$; see also Luke \& Christianson, 2013, for related findings). Nonetheless, the statistical significance of the results was not fully unambiguous, and these data should be taken as suggestive rather than conclusive.

Stemming from these results, Duñabeitia, Perea, and Carreiras (2007) extended the finding that masked TL priming was affected by early morphological effects. In a series of lexical decision experiments with Basque and Spanish speakers, Duñabeitia et al. (2007) found significant masked TL priming effect for polymorphemic words when the letter transposition occurred within a morpheme (vioilnistVIOLINIST), whereas they failed to find a parallel effect for affixed words when the transposed letters crossed the affix boundaries (violiinst-VIOLINIST vs. violierst-VIOLINIST). To explain these findings, the authors suggested the existence of a morpheme detection mechanism operating "early in the process of visual word recognition, co-occurring with mechanisms responsible for assigning letter position" (p. 701; see also Duñabeitia, Perea, \& Carreiras, 2008), akin to the prelexical affix-identification mechanism proposed by Taft and Forster $(1975,1976)$.

However, a recent experiment by Sánchez-Gutiérrez and Rastle (2013) directly disputed the Duñabeitia et al. (2007) findings. The authors reviewed other studies testing English participants in which the magnitudes of TL priming effects were similar in size, regardless of whether or not the transpositions crossed the morphemic boundary (e.g., Beyersmann, Coltheart, \& Castles, 2012; Beyersmann, McCormick, \& Rastle, 2013; Masserang \& Pollatsek, 2012; Rueck1 \& Rimzhim, 2011). They then questioned whether the discrepancy between the data reported by Duñabeitia et al. (2007) and these studies could result from an inherent difference between the languages at test. To test their hypothesis, SánchezGutiérrez and Rastle selected a set of 88 derived words that were cognates between English and Spanish (viz., words with highly similar orthographic, phonological, and semantic representations, such as invisible), and tested English and Spanish participants in a masked-priming TL experiment with a lexical decision task in which the manipulations took place either at the morphemic boundary (i.e., between morphemes) or within morphemes. Sánchez-Gutiérrez and Rastle found masked TL priming effects of similar magnitude for between- and within-morpheme transpositions, as deduced from the lack of a significant interaction. They concluded that "the findings of Duñabeitia et al. reflected idiosyncratic properties of the stimuli or the participants, or a Type I error" (p. 992). Certainly, one of the risks in psycholinguistic studies testing a relatively small set of items is the appearance of a false positive (Type I error). Of course, an identical argument applies to the possibility of reporting a false negative (Type II error), in particular when failing to detect an interaction when the expected effect size is very small.

What is the reason for these incongruent results? Leaving aside issues related to statistical power or to the potential particularities of the stimuli used in the previous experiments, the diverging results for TL manipulations across morphemic boundaries could potentially stem from individual differences in reading skills on morphological decomposition and morpho-orthographic interactions. In a compelling study on morphological priming on words with transparent and opaque relationships (i.e., walker-WALK vs. corner-CORN), Andrews and Lo (2013) demonstrated that the participants' reading styles (orthographic-based vs. semantic-based) modulated the magnitude of these effects, especially in the case of opaque relationships - note that these results have been considered as a marker of morpho-orthographic processing. Although good spellers with average vocabulary (i.e., readers with an orthographic profile) showed significant priming effects for opaque pairs, high-vocabulary participants with average spelling skills (i.e., readers with a semantic profile) showed minimal priming for opaque relationships. Andrews and Lo concluded that the "individual differences approach provides critical, novel evidence that explains the contradictions observed in published average data and provides new evidence that contributes to distinguishing the relative validity of theories of morphological priming" (p. 289).

To examine in detail whether morphological decomposition in suffixed words interacts with letter-position encoding, we conducted a large-scale masked-priming lexical decision experiment including transposed-letter manipulations between morphemes (across morphemic units) and within morphemes. Large-scale experiments partially solve the important issue of statistical power (Keuleers, Diependaele, \& Brysbaert, 2010; see also Button et al., 2013). To this end, we selected a set of 420 suffixed Spanish words and tested 80 participants. Given the relatively large size of the sample, and considering that individual differences in reading skills 
modulate the extent to which a morpho-orthographic style of processing is followed (see Andrews \& Lo, 2013), we divided the group of participants according to their reading speeds (using a median split), and examined whether individual differences could be responsible for the seemingly discrepant results reported in recent years. Previous psycholinguistic research has shown a close interrelation between variations in orthographic processing skills and individual differences in reading (e.g., Perfetti \& Hart, 2001; Stanovich \& West, 1989; see Perfetti, 2007, for review). As was recently reported by Hargreaves, Pexman, Zdrazilova, and Sargious (2012), orthographic skills are inversely correlated with reading speed in the lexical decision task (viz., shorter reaction times [RTs] for participants with high orthographic skills; see also Chateau \& Jared, 2000, and Unsworth \& Pexman, 2003, for a similar argument regarding the influence of increased sublexical skills on reading latencies), and they are also inversely correlated with semantic effects (e.g., participants with enhanced orthographic abilities show reduced effects of concreteness). Hence, following the hypothesis developed by Andrews and Lo regarding the close link between orthographic skills and morpho-orthographic interactions, on the one hand, and considering the evidence suggesting that readers with higher orthographic skills show faster RTs in the lexical decision task than do readers with lower orthographic skills, on the other hand, we expected to find that morpho-orthographic interactions were modulated by reading speed.

\section{Method}

\section{Participants}

A group of 80 undergraduate and graduate students (49 females, 31 males) took part in this experiment. All of them were native Spanish speakers, had normal or corrected-tonormal vision, reported no history of neurological disorder, and signed informed consent forms before the experiment. Their mean age was 25.47 years (range: $18-40, S D=5.94$ ).

\section{Materials}

A set of 420 Spanish suffixed words was selected from B-Pal (Davis \& Perea, 2005). The characteristics of these words are reported in Table 1, and the full list of materials is presented in Appendix A. The set of words included 25 different suffixes, thus comprising a representative subset of Spanish affixed words. These words acted as targets (e.g., VIOLINISTA, violin + ista; translated as violinist) and could be preceded by a prime that was (1) a nonword created by transposing two adjacent letters that crossed the morphemic boundary (TL-between condition; e.g., violiinsta); (2) a nonword created by replacing those two transposed letters with others (replaced-letter [RL]-between condition; e.g., violiersta); (3) a nonword created by transposing two adjacent letters that did not cross the morphemic boundary (TL-within condition; e.g., vioilnista); or (4) a nonword created by replacing those two transposed letters with others (RL-within condition; e.g., vio-

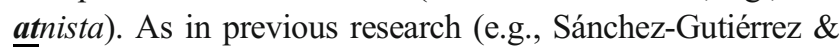
Rastle, 2013), we restricted the criteria for replacements, minimizing the variability in height (i.e., trying to preserve the amount of vertical space occupied by each transposed letter), and replacing letters as a function of their consonantvowel status. None of the letter transpositions or replacements involved two vowels (see Perea \& Acha, 2009, for a demonstration of weaker TL effects for vowel combinations than for manipulations involving consonants) or the initial or final letters of the strings, and all of the bigrams manipulated resulted in existing letter combinations in Spanish (see Frankish \& Turner, 2007). Special attention was paid to the frequencies of the manipulated bigrams, which were matched across TL and RL conditions in a pairwise manner: TLbetween $=2,210.63$, RL-between $=2,250.59$, paired samples $t(419)=-1.11, p=.27$; TL-within $=1,639.22$, RL-within $=$ 1,625.74, paired samples $t(419)=0.32, p=.75$ (see Frankish \& Barnes, 2008, and Perea \& Carreiras, 2008, for evidence regarding the importance of matching the different conditions in their bigram frequencies). Additionally, a set of 420 Spanish nonword targets was created (e.g., DULEFO; see Appendix A). We used Wuggy (Keuleers \& Brysbaert, 2010) to create these nonwords from the real words; this program provides a valid matching of the items in subsyllabic structure and transition frequencies. These nonwords were matched to the words in length in a pairwise manner, they respected Spanish orthotactics, and they had bigram frequencies and orthographic neighborhoods similar to those of the word set (for the words: mean length $=8.97$, mean type bigram frequency $=369.24$, mean token bigram frequency $=$ 77.11 , mean $N=0.37$; for the nonwords: mean length $=8.98$, mean type bigram frequency $=341.69$, mean token bigram frequency $=70.09$, mean $N=0.04$ ). Considering the specific characteristics of the matching algorithm used by Wuggy, some nonwords ended in a sequence of letters that matched a real Spanish suffix, and others did not. Half of the nonword targets were preceded by a nonword prime that included an internal adjacent transposition, and half were preceded by a nonword prime that included a doubleletter replacement. The manipulations carried out in the nonwords were distributed among different string (internal) locations, in order to emulate the manipulations in the word set. All of the word targets appeared in each of the four lists that were created, but each time in a different priming condition. Twenty participants completed each of the four lists, following a counterbalanced design. 
Table 1 Characteristics (means, standard deviations [SDs], minimum values, and maximum values) of the different indices of the words used in the experiment

\begin{tabular}{|c|c|c|c|c|}
\hline & Mean & $S D$ & Min & Max \\
\hline Word frequency (per million) & 4.13 & 6.84 & 0.18 & 65.54 \\
\hline Word length (in number of letters) & 8.97 & 1.41 & 6 & 12 \\
\hline Word $N$ & 0.37 & 0.67 & 0 & 4 \\
\hline Base frequency (per million) & 32.40 & 64.30 & 0.18 & 689.82 \\
\hline Base length (in number of letters) & 6.56 & 1.46 & 3 & 10 \\
\hline Base $N$ & 1.80 & 2.71 & 0 & 24 \\
\hline Suffix length (in number of letters) & 3.25 & 0.68 & 2 & 5 \\
\hline Levenshtein distance between base and root (in number of edits) & 1.01 & 0.55 & 0 & 5 \\
\hline Base morphological family & 5.21 & 2.95 & 2 & 22 \\
\hline Suffix morphological family & 338.18 & 166.52 & 10 & 525 \\
\hline Base cumulative frequency (per million) & 70.51 & 101.51 & 0.36 & 832.87 \\
\hline Suffix cumulative frequency (per million) & $1,102.71$ & 967.67 & 5.55 & $4,357.84$ \\
\hline Boundaries' bigram frequency & $2,587.98$ & $1,302.87$ & 47 & 4,511 \\
\hline
\end{tabular}

Procedure

The experiment was conducted in acoustically shielded individual test cabins, using PCs (Dell Optiplex 760) with CRT monitors working at $1,024 \times 768$ and $90 \mathrm{~Hz}$. Stimulus presentation and data collection were controlled by DMDX software (Forster \& Forster, 2003). Each trial consisted of the centered presentation of a mask (\# symbols) for $500 \mathrm{~ms}$, followed by brief presentation of the prime in lowercase Courier New font for $55 \mathrm{~ms}$ (five cycles of $11.11 \mathrm{~ms}$ each). After this, the target appeared in uppercase letters and stayed on the screen for $2,500 \mathrm{~ms}$ or until the participant responded. The length of the mask varied from trial to trial, depending on the number of characters in the primes/targets. Participants had to press one of two labeled buttons on an Empirisoft DirectIN High Speed Button-Box, to indicate whether the displayed string was or was not an existing word in Spanish. They were instructed to do so as quickly and accurately as possible, and they were trained with a short practice consisting of ten words and ten nonwords. All of the experimental items were randomly presented. The whole experimental session lasted approximately $20 \mathrm{~min}$.

\section{Results}

Trials associated with erroneous responses (3.94\%) and response latencies faster than $250 \mathrm{~ms}$ or slower than $1,500 \mathrm{~ms}$ ( $3.37 \%)$ were excluded from the RT analysis. Then, a mediansplit procedure was followed in order to identify faster and slower participants (see Häikiö, Bertram, Hyönä, \& Niemi, 2009, for a similar procedure). The mean RT for each participant across word and nonword trials was calculated, and individual participants were then split into two groups, depending on whether their mean RT fell above (i.e., slower group) or below (i.e., faster group) the median RT value of the averaged latencies for the whole set of items (median $=741 \mathrm{~ms}$, mean $=$ $761 \mathrm{~ms}, S D=144 \mathrm{~ms})$. The slower group $(N=40)$ had a mean overall RT of $881 \mathrm{~ms}(S D=94 \mathrm{~ms})$, whereas the faster group $(N=40)$ had a mean RT of $641 \mathrm{~ms}(S D=62 \mathrm{~ms})$. Next, participant- and item-based analyses of variance (ANOVAs) were run on the word data following a $2 \times 2 \times 2 \times 4$ design, including the factors Place of Manipulation (within $\mid$ between), Type of Manipulation (TL $\mid$ RL), Group (slower | faster), and List (1 $|2| 3 \mid 4)$; List was included as a dummy variable in the design (Pollatsek \& Well, 1995). The mean RTs and percentages of errors for each group and condition are presented in Table 2 .

The ANOVAs on the RTs for the word trials showed a main effect of place of manipulation $\left[F_{1}(1,72)=43.82, p<.001\right.$; $\left.F_{2}(1,416)=58.52, p<.001\right]$ and a main effect of type of manipulation $\left[F_{1}(1,72)=32.98, p<.001 ; F_{2}(1,416)=36.05\right.$, $p<.001]$. The effect of group was also significant $\left[F_{1}(1,72)=\right.$ $\left.170.22, p<.001 ; F_{2}(1,416)=5,856.25, p<.001\right]$. Critically, the three-way interaction was significant $\left[F_{1}(1,72)=9.46\right.$, $\left.p=.003 ; F_{2}(1,416)=6.80, p=.009\right]$. Separate analyses were conducted for the faster and slower groups, to understand the origin of this interaction. For the faster participants, we observed a significant two-way interaction between place of manipulation and type of manipulation $\left[F_{1}(1,36)=15.31\right.$, $\left.p<.001 ; F_{2}(1,416)=9.77, p=.002\right]$, reflecting a sizeable 18 -ms TL effect for within-morpheme manipulations $(\mathrm{TL}=597 \mathrm{~ms}, \mathrm{RL}=615 \mathrm{~ms})\left[F_{1}(1,36)=49.84, p<.001\right.$; $\left.F_{2}(1,416)=34.18, p<.001\right]$, but not for between-morpheme manipulations $(\mathrm{TL}=589 \mathrm{~ms}, \mathrm{RL}=593 \mathrm{~ms})\left[F_{1}(1,36)=2.36\right.$, $\left.p=.13 ; F_{2}(1,416)=2.61, p=.11\right]$. In contrast, the critical interaction did not approach significance for the slower participants $\left[F_{1}(1,36)=1.37, p=.25 ; F_{2}(1,416)=1.09, p=.30\right]$; note that both the place of manipulation $\left[F_{1}(1,36)=15.12\right.$, $\left.p<.001 ; F_{2}(1,416)=20.40, p<.001\right]$ and type of 
Table 2 Means and standard deviations of the lexical decision times (in milliseconds) and percentages of errors (within parentheses) for the word targets across the different conditions and groups

\begin{tabular}{|c|c|c|c|c|c|c|}
\hline \multirow[b]{2}{*}{ Group } & \multicolumn{3}{|c|}{ Within-Morpheme } & \multicolumn{3}{|c|}{ Between Morphemes } \\
\hline & $\mathrm{TL}$ & $\mathrm{RL}$ & Priming & $\mathrm{TL}$ & RL & Priming \\
\hline All & $701(4.87 \%)$ & $714(5.24 \%)$ & $13(0.37 \%)$ & $688(4.23 \%)$ & $698(4.13 \%)$ & $10(-0.10 \%)$ \\
\hline Slower & $804(5.02 \%)$ & $813(4.90 \%)$ & $9(-0.12 \%)$ & $788(4.45 \%)$ & $804(4.57 \%)$ & $16(0.12 \%)$ \\
\hline Faster & $597(4.71 \%)$ & $615(5.57 \%)$ & $18(0.86 \%)$ & $589(4.00 \%)$ & $593(3.69 \%)$ & $4(-0.31 \%)$ \\
\hline
\end{tabular}

Priming effects were calculated by subtracting the transposed-letter (TL) conditions from the replaced-letter (RL) conditions. The mean RTs and percentages of errors associated with nonword trials were $821 \mathrm{~ms}(3.29 \%)$ in the TL condition and $830 \mathrm{~ms}(3.26 \%)$ in the RL condition for the whole group of participants; $964 \mathrm{~ms}(4.18 \%)$ in the TL condition and $972 \mathrm{~ms} \mathrm{(3.77 \% )} \mathrm{in} \mathrm{the} \mathrm{RL} \mathrm{condition} \mathrm{for} \mathrm{the} \mathrm{slower} \mathrm{group;} \mathrm{and} 678 \mathrm{~ms}(2.40 \%)$ in the TL condition and $688 \mathrm{~ms}(2.74 \%)$ in the RL condition for the faster group

manipulation $\left[F_{1}(1,36)=12.81, p<.001 ; F_{2}(1,416)=16.19\right.$, $p<.001]$ main effects were significant—-the overall TL priming effect was 12 ms. ${ }^{1}$

The analysis on the error data showed a main effect of place of manipulation $\left[F_{1}(1,72)=22.01, p<.001 ; F_{2}(1,416)=\right.$ $18.00, p<.001]$ that interacted with group in the analysis by participants $\left[F_{1}(1,72)=4.36, p=.04 ; F_{2}(1,416)=2.94, p=\right.$ $.09]$. This revealed that within-morpheme manipulations led to higher error rates than did manipulations between morphemes, and that this difference was larger for the faster than for the slower group (a $1.30 \%$ and a $0.45 \%$ difference, respectively). No other effects/interactions were significant.

In sum, the present data reveal that for faster readers, TL priming effects were greater for within-morpheme than for between-morpheme transpositions, whereas no such difference occurred for the slower readers. ${ }^{2}$ To obtain further evidence of the relationship between the overall RTs of the whole group of participants and the magnitudes of the TL effects

\footnotetext{
${ }^{1}$ As can be seen in Table 2, the two RL conditions led to significantly different RTs (shorter RTs for between-morpheme RL than for withinmorpheme RL). This difference is similar to that observed by SánchezGutiérrez and Rastle (2013) in their suffixed sets of Spanish and English words ( 8 and $7 \mathrm{~ms}$, respectively), and a similar difference was found by these authors in the error rates. Similarly, Duñabeitia et al. (2007) also found a difference of $9 \mathrm{~ms}$ between these conditions. Nonetheless, it should be considered that these differences in the RL conditions are not of special theoretical or experimental interest, given that transposed-letter effects are the result of substracting the TL and RL conditions in a manner that is sensitive to the location where the manipulations are carried out within the strings (between and within morphemes, separately).

2 A parallel analysis was carried out for word trials using the participants' $z$ transformed averaged data in each condition, in order to compensate for individual participants' processing speed differences (see Faust, Balota, Spieler, \& Ferraro, 1999). The results fully replicated the analysis carried out on the nontransformed data, showing a significant three-way interaction $[F(1,36)=11.32, p=.001]$. The critical two-way interaction between place of manipulation and type of manipulation was significant for the faster group $[F(1,36)=13.45, p=.001]$, whereas it was not for the slower group, who showed a generalized TL effect [type of manipulation, $F(1,36)=11.57, p=$ .002 ; interaction, $F(1,36)=1.09, p=.304]$. The faster group showed a significant type of manipulation effect within morphemes $[F(1,36)=50.84$, $p<.001]$, but not between morphemes $[F(1,36)=2.08, p=.158]$.
}

within and between morphemes, two additional analyses were conducted. First, the magnitude of the TL effect for the withinmorpheme manipulation was calculated for each participant $(N=80)$. The individual within-morpheme TL effects did not significantly correlate with the participants' mean RTs $[r=$ $-.14, t(78)=1.22, p=.22]$, showing that this effect was relatively independent from the processing speed. Importantly, the magnitude of the TL effect in the betweenmorpheme condition was positively correlated with the participants' overall RTs $[r=.26, t(78)=2.40, p=.02]$, showing that the magnitude of the critical between-morpheme TL effect increased as a function of the general processing speed in the task (see Fig. 1).

Second, to further examine the manner in which the magnitude of TL priming effects is modulated by the participant's rapidity in the task, we reexamined the data using a centilebased analysis of the RT distribution (see Andrews \& Lo, 2013; Balota, Yap, Cortese, \& Watson, 2008; and Yap, Tse, \& Balota, 2009, for similar approaches; see also Ratcliff, 1979, for a description of the advantages of examining RT distributions over mean RTs, and Johnson, Staub, \& Fleri, 2012, for further evidence regarding the relationship between reading speed and TL effects). We computed the RT distributions in each critical condition and obtained nine representative centiles (from the 10th to the 90th centiles, in steps of 10; see Fig. 2). Then we calculated the difference of the magnitudes of the TL effects for the between-morpheme and withinmorpheme conditions for each participant. As can be seen in Fig. 2, the TL effects for within-morpheme manipulations were relatively unaffected by the speed of response, coinciding with the results from the correlational analyses. In contrast, the TL effects for between-morpheme manipulations increased as a function of the speed of response. ANOVAs performed on the whole set of data showed significant interactions between place of manipulation and type of manipulation in the 10th, 20th, 30th and 40th centiles (all $F_{\mathrm{s}}>4$, all $p \mathrm{~s}<.05$ ), whereas the interaction was negligible in the upper centiles (all $F \mathrm{~s}<1$, all $p \mathrm{~s}>.30$ ). Besides, as can also be observed in Fig. 2, the within- and between-morpheme TL 
a)

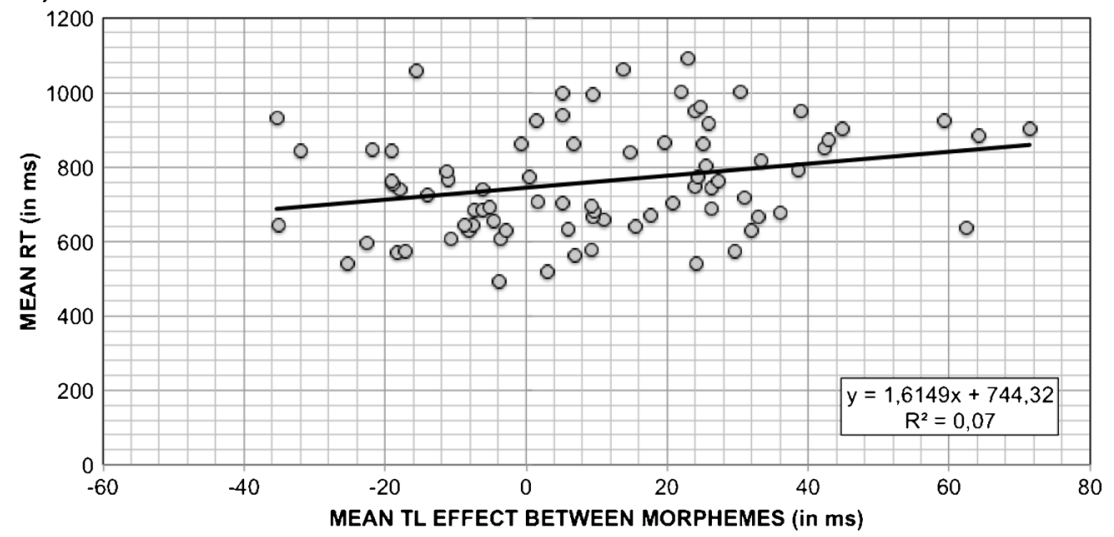

b)

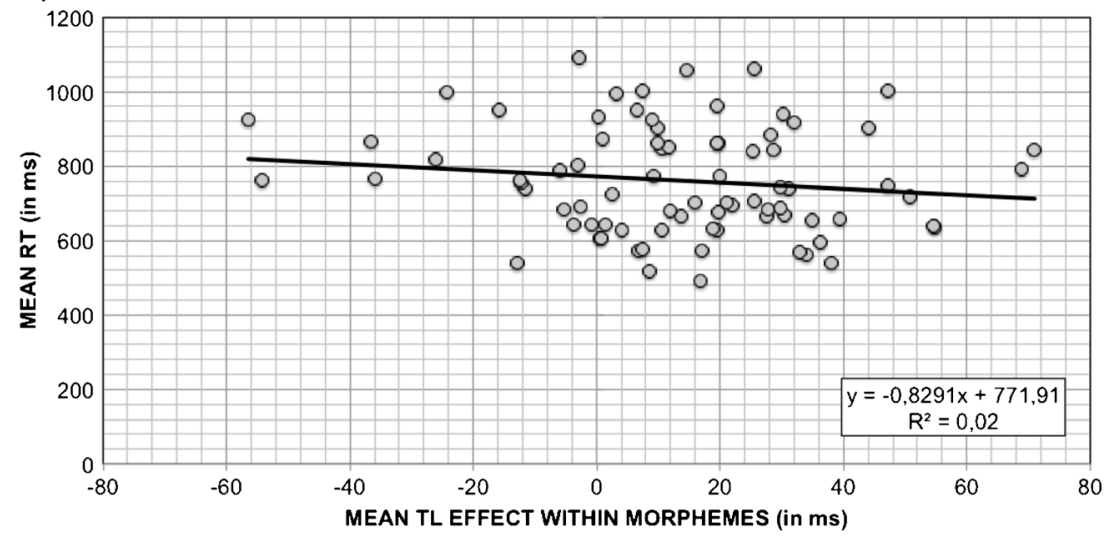

Fig. 1 Scatterplots of the mean transposed-letter (TL) effects (between morphemes [panel a] and within morphemes [panel b], respectively) for the whole set of participants as a function of the participants' mean reaction times (RTs) in the lexical decision task

priming effects were clearly different from each other in the group of faster readers, and this difference held constant across the entire RT distribution.

\section{Discussion}

The present large-scale masked-priming experiment helps reconcile earlier research on the interaction between early orthographic coding and morphological decomposition processes, by providing a tentative explanation for the divergent results reported in recent years. First, as Sánchez-Gutiérrez and Rastle (2013) observed, it is possible to obtain (fairly small) masked-priming effects when the transposed-letter manipulation crosses the affix boundary (around $10 \mathrm{~ms}$, when averaging faster and slower readers), thus suggesting that the null effect reported in our earlier study (Duñabeitia et al., 2007) may have been the consequence of a Type II error (viz., a false negative). Second, and more importantly, when the individual differences of the participants in their reading speeds were taken into account, clear-cut differences emerged in the magnitudes of the TL priming effects for between- and within-morpheme manipulations. Specifically, even though the slower participants showed significant TL priming effects, irrespectively of the place of manipulation (hence replicating the results of Sánchez-Gutiérrez \& Rastle, 2013, among others), the group of faster participants only showed TL priming effects in within-morpheme conditions, but not between morphemes (replicating Duñabeitia et al., 2007, among others). Hence, the present data demonstrate that the interaction reported by Duñabeitia et al. (2007) was not the result of a Type I error (a false positive), and that the null interaction effect reported by Sánchez-Gutiérrez and Rastle for the Spanish set is not a fully generalizable finding, given that it is dependent on the participants' reading performance. These observations were further reinforced by correlational analyses and RT distributional analyses.

The present results add to a growing body of literature demonstrating the impact of individual differences in reading skills on the different stages of word processing (see Chace, Rayner, \& Well, 2005; Häikiö et al., 2009; Janack, Pastizzo, \& Feldman, 2004; Rayner, Slattery, \& Bélanger, 2010; Yap, Tse, \& Balota, 2009; Ziegler, Jacobs, \& Klüppel, 2001, to cite just a few examples). Of particular interest is the recent study by Andrews and Lo (2013), in which the participants' reading "profiles" (orthographic vs. semantic) modulated the 
a)

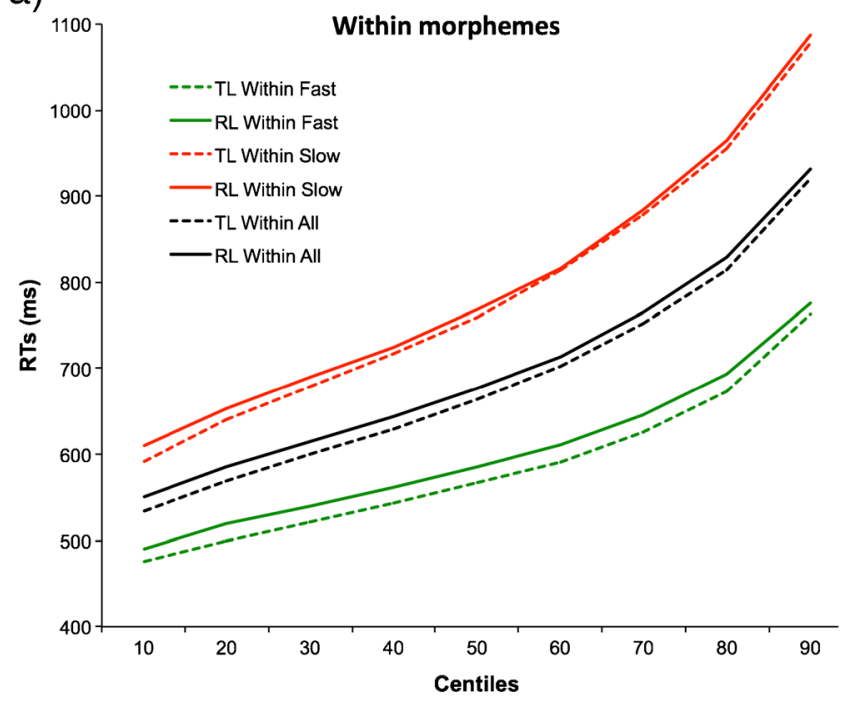

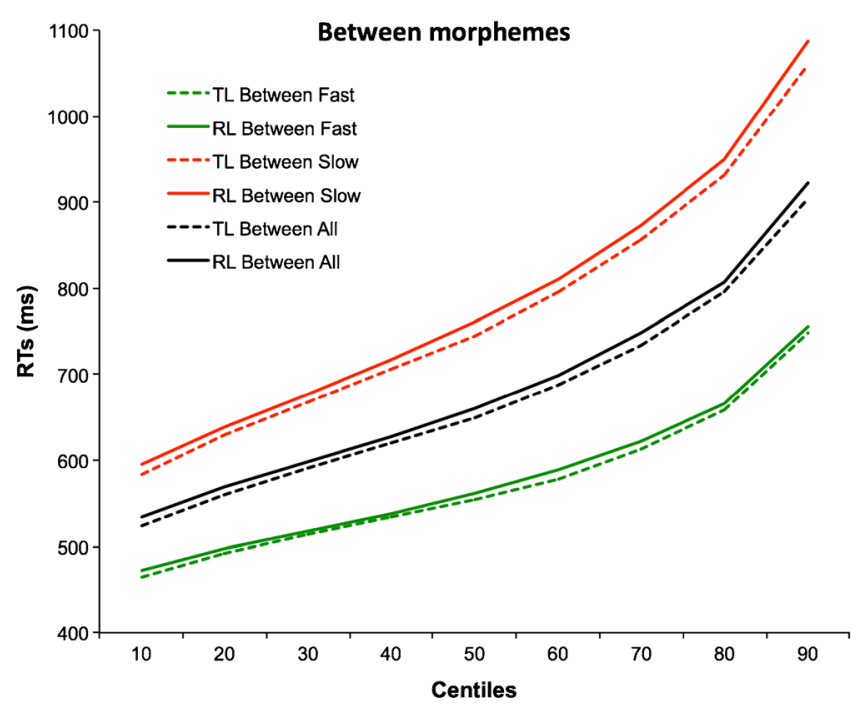

b)

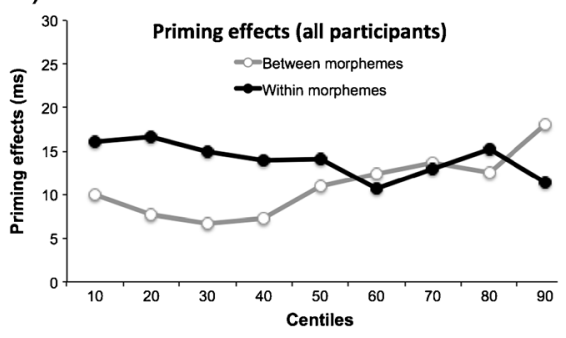

Fig. 2 (a) Averaged reaction time (RT) distributions for the whole sample of participants ( $N=80$, central lines), and for the slow and fast groups ( $n=40$ each; top and bottom lines, respectively) in the transposedletter (TL) and replaced-letter (RL) conditions (dotted and solid lines,
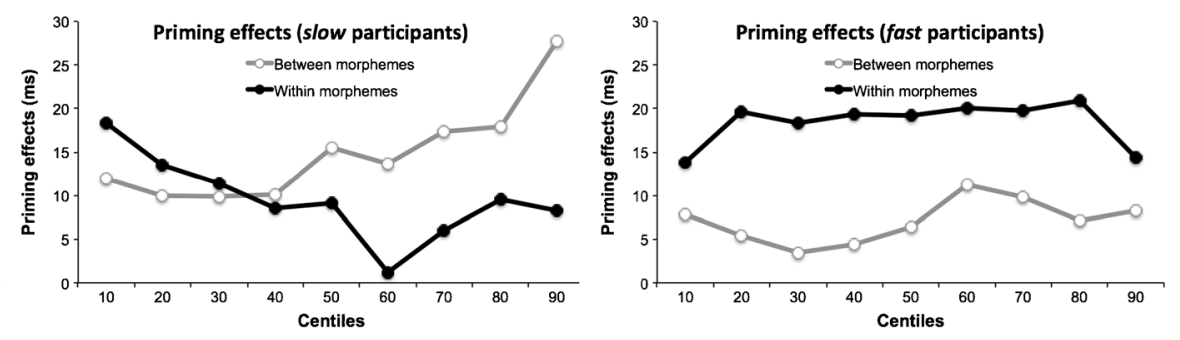

respectively) for the between- and within-morpheme manipulations. (b) Scattering of the difference between the TL effects for the within- and between-morpheme manipulations according to the 10th- to 90th-centile distribution for the whole sample and for the slow and fast groups

(Christianson et al., 2005, Exp. 3; Duñabeitia et al., 2007; see also Luke \& Christianson, 2013, for additional evidence), and support a claim for the existence, at least for the most skilled readers, of an early stage of morphological decomposition that is sensitive to morpho-orthographic interactions (see also Taft \& Nillsen, 2013). More importantly, the present study offers an (admittedly speculative, but suggestive) explanation for the different results that have been provided in recent studies on the same issue (see Beyersmann et al., 2013; Rueckl \& Rimzhim, 2011; Sánchez-Gutiérrez \& Rastle, 2013).

We suggest that TL effects across morphemes do not respond to a dichotomous all-or-nothing reality. Instead, TL effects across morphemic boundaries can be captured better by a continuum that may be linked to individual differences in reading performance and/or to participants' reading styles/ profiles. Considering the tight link between reading efficiency and orthographic knowledge (see, e.g., Perfetti, 2007), and taking into account recent evidence demonstrating that increased orthographic skills lead to shorter RTs in the lexical decision task (e.g., Hargreaves et al., 2012), we initially hypothesized that the faster participants would be the ones with an increased sensitivity to morpho-orthographic factors, and not the morphological properties of the words are kept intact 
consequently the ones who would show minimal TL effects between morphemes. The results of the present experiment fully satisfied this hypothesis, suggesting that faster readers follow a reading style based on fast-acting automatic morphological decomposition processes (akin to the morpho-orthographic account proposed by, among others, Diependaele, Sandra, \& Grainger, 2005). In contrast, the slower readers are hypothesized to focus less on orthographic information, probably basing their reading profile on semantic-based pieces of information (note, for instance, that the concreteness effect is inversely correlated with the orthographic skills of the readers, as was shown by Hargreaves et al., 2012). In this line, we found that slower readers showed no morpho-orthographic interactions and robust between-morpheme TL effects. In spite of the strength of the analyses reported here, we acknowledge that further studies should be aimed at reexamining the relationship between reading speed, orthographic skill, and morpho-orthographic interactions, probably using fully independent indices for each construct.

At a methodological level, we believe that one of the most efficient avenues to shed more light on the existence of morpho-orthographic interactions will be the implementation of masked-priming experiments testing: (1) a sufficiently large and heterogeneous sample of items that are representative of each language, and (2) a large sample of participants with varying degrees of reading skills. This joint approach may provide enough power to detect small differences that are inherent in subtle manipulations, as we have demonstrated in the present experiment. Following this strategy, the present data reinforce the view that although large effects in masked priming are reliable and consistent across labs, "anything finer-grained is extremely difficult to detect" (Gomez et al., 2008 , p. 598), at least in typical experiments testing subtle effects with a relatively small set of words per condition. Furthermore, a large-scale approach would allow researchers to explore whether the individual characteristics of the words modulate the pattern of priming effects. In this light, we tested whether (and how) the specific properties of the words used in the experiment had an influence on the magnitude of the critical TL effect between morphemes in a set of regression analyses (see Appendix B). The results of these analyses did not highlight any relevant property of the words as being a modulating factor for slower readers. Similarly, the regression models for faster readers showed relatively poor fits, thus leading to the conclusion that the reason for the differences in the magnitudes of the TL effect is not "idiosyncratic properties of the stimuli," as was suggested by Sánchez-Gutiérrez and Rastle (2013).

To sum up, the present data suggest that the process of letter position coding is not completely blind to the context in which the manipulations take place (e.g., between morphological units) or to the individual differences of the participants in their reading skills. Taking into account the data provided by Andrews and Lo (2013) and the present results, further research should try to clarify the influence of orthographic skill in the morphological decomposition of polymorphemic words.

Author Note This research was partially supported by Grant Nos. CSD2008-00048, PSI2011-26924, and PSI2012-32123 from the Spanish government; ERC-AdG-295362 from the European Research Council; and PI2012-74 from the Basque government. We are extremely thankful to Ainhara Martí, who helped us with the creation of the materials and with a pilot data collection, and to Margaret Gillon Dowens, Kiel Christianson, Kathy Rastle, and Sachiko Kinoshita for their helpful comments on earlier drafts of the manuscript.

\section{Appendix A}

Table 3 Word and nonword items

\begin{tabular}{|c|c|c|c|c|c|}
\hline $\begin{array}{l}\text { TARGET } \\
\text { WORD }\end{array}$ & $\begin{array}{l}\text { TARGET } \\
\text { NONWORD }\end{array}$ & $\begin{array}{l}\text { TL BETWEEN } \\
\text { MORPHEMES }\end{array}$ & $\begin{array}{l}\text { TL WITHIN } \\
\text { MORPHEME }\end{array}$ & $\begin{array}{l}\text { RL BETWEEN } \\
\text { MORPHEMES }\end{array}$ & $\begin{array}{l}\text { RL WITHIN } \\
\text { MORPHEME }\end{array}$ \\
\hline dulzura & dagmura & duluzra & dluzura & duloxra & dbezura \\
\hline vencedor & fandedor & vencdeor & vnecedor & venctoor & vmicedor \\
\hline ricachón & siradron & ricacóhn & riacchón & ricacébn & riischón \\
\hline quemadura & neucasura & quemdaura & qumeadura & quemteura & qusaadura \\
\hline vecindario & leroncario & vecinadrio & veicndario & vecinolrio & veenndario \\
\hline determinismo & depengilisto & determiinsmo & detreminismo & determiersmo & detcaminismo \\
\hline florista & clolusta & floirsta & folrista & floemsta & fadrista \\
\hline resultón & renopton & resulótn & reslutón & resulédn & resbetón \\
\hline detonador & demisadar & detondaor & deotnador & detonteor & deednador \\
\hline mujeriego & muhireifo & mujeirego & muejriego & mujeemego & muipriego \\
\hline poseedor & bomaodor & posedeor & poesedor & posetoor & pouredor \\
\hline
\end{tabular}


Table 3 (continued)

\begin{tabular}{|c|c|c|c|c|c|}
\hline $\begin{array}{l}\text { TARGET } \\
\text { WORD }\end{array}$ & $\begin{array}{l}\text { TARGET } \\
\text { NONWORD }\end{array}$ & $\begin{array}{l}\text { TL BETWEEN } \\
\text { MORPHEMES }\end{array}$ & $\begin{array}{l}\text { TL WITHIN } \\
\text { MORPHEME }\end{array}$ & $\begin{array}{l}\text { RL BETWEEN } \\
\text { MORPHEMES }\end{array}$ & $\begin{array}{l}\text { RL WITHIN } \\
\text { MORPHEME }\end{array}$ \\
\hline enfermero & enmislero & enferemro & enfremero & enferirro & enfcamero \\
\hline paracaidista & sagemiadista & paracaiidsta & parcaaidista & paracaialsta & parreaidista \\
\hline voladura & bomasuro & voldaura & vloadura & volteura & vdiadura \\
\hline regulador & bafuladar & reguldaor & reuglador & regulteor & reijlador \\
\hline hechicero & betletero & hechiecro & hecihcero & hechiasro & hecufcero \\
\hline delgadez & detmidez & delgaedz & delagdez & delgaotz & delopdez \\
\hline medallón & sedallal & medalóln & meadllón & medaládn & meolllón \\
\hline dictadura & mostatura & dictdaura & dcitadura & dictteura & dnatadura \\
\hline nitidez & nitadid & nitiedz & niitdez & nitiotz & niafdez \\
\hline donante & tovonte & donnate & dnoante & doncite & dseante \\
\hline piratería & sodemeria & piraetría & piartería & piraulría & piontería \\
\hline jardinería & nonlaneria & jardienría & jaridnería & jardiicría & jaralnería \\
\hline embarcadero & ertulnadero & embarcdaero & embracadero & embarcteero & embcocadero \\
\hline calidez & caradiz & caliedz & caildez & caliotz & caatdez \\
\hline chispeante & glosciante & chispenate & chsipeante & chispecite & chmopeante \\
\hline costero & cascera & cosetro & csotero & cosulro & ccutero \\
\hline cantante & canreste & cantnate & cnatante & cantcite & ccitante \\
\hline estimulador & esmacuradar & estimuldaor & estiumlador & estimulteor & estiavlador \\
\hline luchador & vutridor & luchdaor & lcuhador & luchteor & 1sohador \\
\hline imaginario & isefiraria & imagianrio & imaignario & imagiorrio & imaepnario \\
\hline voluminoso & bonunilozo & volumionso & voluimnoso & volumiarso & voluunnoso \\
\hline excitante & erfenante & excitnate & exctiante & excitcite & excleante \\
\hline narrador & tadridor & narrdaor & nrarador & narrteor & ncorador \\
\hline sexagenario & songepenario & sexageanrio & sexaegnario & sexageorrio & sexaapnario \\
\hline conocedor & dimocodor & conocdeor & concoedor & conoctoor & conraedor \\
\hline cocotero & dimomero & cocoetro & cooctero & cocoulro & coivtero \\
\hline matadero & pamasera & matdaero & mtaadero & matteero & mliadero \\
\hline flacucho & clatublo & flauccho & falcucho & flaizcho & fidcucho \\
\hline flotador & blocidor & flotdaor & foltador & flotteor & fadtador \\
\hline soldador & sulsidor & solddaor & slodador & soldteor & sdidador \\
\hline motorista & momorenca & motoirsta & mootrista & motoemsta & moedrista \\
\hline positivismo & sosamibisto & positiivsmo & posiitvismo & positiocsmo & posiafvismo \\
\hline dibujante & mimugunte & dibujnate & dibjuante & dibujcite & dibyeante \\
\hline escalador & anfagador & escaldaor & esclaador & escalteor & escdoador \\
\hline pescador & senrador & pescdaor & psecador & pescteor & pnocador \\
\hline telefonazo & henagonaso & telefoanzo & teleofnazo & telefoorzo & teleebnazo \\
\hline comunicante & toluceconte & comunicnate & comnuicante & comuniccite & comzoicante \\
\hline golfista & fuljista & golifsta & glofista & goludsta & gdifista \\
\hline rotulador & bomugadar & rotuldaor & rotluador & rotulteor & rotbeador \\
\hline obligatorio & ocrejatecio & obligtaorio & oblgiatorio & obligdoorio & oblpoatorio \\
\hline pajarería & sazirolia & pajaerría & paajrería & pajainría & paiqrería \\
\hline simplista & domblista & simpilsta & smiplista & simpatsta & sneplista \\
\hline dormitorio & dalmelorio & dormtiorio & dromitorio & dormleorio & dmamitorio \\
\hline adaptador & afecnador & adaptdaor & adpatador & adaptteor & adgotador \\
\hline pajarraco & mafadrano & pajararco & paajrraco & pajaronco & paiqrraco \\
\hline frescura & clenlura & fresucra & frsecura & fresizra & frnocura \\
\hline estirón & encirin & estiórn & esitrón & estiánn & esafrón \\
\hline triunfante & pransfante & triunfnate & trinufante & triunfcite & trizofante \\
\hline
\end{tabular}


Table 3 (continued)

\begin{tabular}{|c|c|c|c|c|c|}
\hline $\begin{array}{l}\text { TARGET } \\
\text { WORD }\end{array}$ & $\begin{array}{l}\text { TARGET } \\
\text { NONWORD }\end{array}$ & $\begin{array}{l}\text { TL BETWEEN } \\
\text { MORPHEMES }\end{array}$ & $\begin{array}{l}\text { TL WITHIN } \\
\text { MORPHEME }\end{array}$ & $\begin{array}{l}\text { RL BETWEEN } \\
\text { MORPHEMES }\end{array}$ & $\begin{array}{l}\text { RL WITHIN } \\
\text { MORPHEME }\end{array}$ \\
\hline apagón & adimon & apaógn & aapgón & apaápn & aeggón \\
\hline blusón & drunon & bluósn & bulsón & bluámn & betsón \\
\hline determinista & decanjilista & determiinsta & detreminista & determiersta & detcaminista \\
\hline barrigón & larravon & barriógn & barirgón & barriápn & baremgón \\
\hline encefalitis & endabalimes & encefailtis & enceaflitis & encefaattis & enceitlitis \\
\hline adiestrador & apiarflador & adiestrdaor & adisetrador & adiestrteor & adinotrador \\
\hline circulatorio & doctulatoria & circultaorio & circluatorio & circuldoorio & circbeatorio \\
\hline simulador & bomudadar & simuldaor & siumlador & simulteor & siavlador \\
\hline esponjoso & escucnoso & esponojso & espnojoso & esponupso & espsejoso \\
\hline humanismo & busaristo & humainsmo & huamnismo & humaersmo & huosnismo \\
\hline programador & proflifadar & programdaor & progarmador & programteor & progonmador \\
\hline torturador & hispurador & torturdaor & tortruador & torturteor & tortveador \\
\hline analizador & aleripadar & analizdaor & anlaizador & analizteor & andoizador \\
\hline comunista & comularna & comuinsta & coumnista & comuersta & coavnista \\
\hline fulminante & hoslinante & fulminnate & fulmniante & fulmincite & fulmceante \\
\hline acelerador & alareladar & acelerdaor & acelreador & acelerteor & acelcaador \\
\hline frutería & frulicio & fruetría & furtería & fruulría & festería \\
\hline visitante & bimenante & visitnate & vistiante & visitcite & visleante \\
\hline comunismo & comucarso & comuinsmo & coumnismo & comuersmo & coavnismo \\
\hline navideño & gadedepo & naviedño & naivdeño & naviotño & naocdeño \\
\hline espumoso & enmusovo & espuomso & esupmoso & espuusso & esojmoso \\
\hline recibidor & pemefidor & recibdior & reicbidor & recibloor & reenbidor \\
\hline funcionario & humpianario & funcioanrio & funiconario & funcioorrio & funenonario \\
\hline pegamento & mepadenta & pegmaento & pgeamento & pegroento & pjaamento \\
\hline segador & mepidor & segdaor & sgeador & segteor & sjaador \\
\hline legionario & bevierario & legioanrio & leigonario & legioorrio & leeponario \\
\hline habitante & bafenante & habitnate & habtiante & habitcite & hableante \\
\hline terrorismo & beflocisco & terroirsmo & terorrismo & terroemsmo & teranrismo \\
\hline corredor & cefleror & corrdeor & croredor & corrtoor & cmaredor \\
\hline tabernero & vabanlero & taberenro & taebrnero & tabericro & taofrnero \\
\hline solidario & mocilaria & soliadrio & soildario & soliolrio & soatdario \\
\hline hogareño & bodanefo & hogaerño & hoagreño & hogainño & hoopreño \\
\hline churrero & grufleto & churerro & chrurero & churinro & chverero \\
\hline dulzón & dusbon & dulózn & dluzón & duláxn & dbezón \\
\hline entendedor & ensargedor & entenddeor & entnededor & entendtoor & entmidedor \\
\hline lavadero & bafasera & lavdaero & lvaadero & lavteero & lñoadero \\
\hline pasador & mapidor & pasdaor & psaador & pasteor & pmeador \\
\hline brasero & clacera & braesro & barsero & braurro & bonsero \\
\hline robustez & sogostez & robusetz & roubstez & robusulz & roodstez \\
\hline simpatizante & sonsetijante & simpatiznate & simptaizante & simpatizcite & simpliizante \\
\hline seguidor & meviodor & segudior & sgeuidor & seguloor & sjauidor \\
\hline pastelería & sorteroria & pasteelría & pasetlería & pasteabría & pasullería \\
\hline ligadura & bicaluro & ligdaura & lgiadura & ligteura & lpoadura \\
\hline zapatero & bamacera & zapaetro & zaaptero & zapaulro & zaegtero \\
\hline rapidez & savidiz & rapiedz & raipdez & rapiotz & raejdez \\
\hline dormilón & dalcilon & dormióln & dorimlón & dormiádn & dorunlón \\
\hline sancionador & moncuicador & sanciondaor & sancinoador & sancionteor & sanciseador \\
\hline organizador & osbemizadar & organizdaor & organziador & organizteor & organxuador \\
\hline
\end{tabular}


Table 3 (continued)

\begin{tabular}{|c|c|c|c|c|c|}
\hline $\begin{array}{l}\text { TARGET } \\
\text { WORD }\end{array}$ & $\begin{array}{l}\text { TARGET } \\
\text { NONWORD }\end{array}$ & $\begin{array}{l}\text { TL BETWEEN } \\
\text { MORPHEMES }\end{array}$ & $\begin{array}{l}\text { TL WITHIN } \\
\text { MORPHEME }\end{array}$ & $\begin{array}{l}\text { RL BETWEEN } \\
\text { MORPHEMES }\end{array}$ & $\begin{array}{l}\text { RL WITHIN } \\
\text { MORPHEME }\end{array}$ \\
\hline frenazo & brenimo & freanzo & fernazo & freorzo & finnazo \\
\hline hablador & naflidor & habldaor & hbalador & hablteor & hfelador \\
\hline paredón & sacedos & pareódn & paerdón & pareíbn & paindón \\
\hline resultante & remecnante & resultnate & reslutante & resultcite & resbetante \\
\hline modernista & movanlista & moderinsta & modrenista & moderersta & modcanista \\
\hline cursilería & dorbirelia & cursielría & curislería & cursiabría & curaclería \\
\hline explorador & asgrirador & explordaor & expolrador & explorteor & expadrador \\
\hline ocupante & omubince & ocupnate & ocpuante & ocupcite & ocjeante \\
\hline gallinero & nafretero & gallienro & galilnero & galliicro & galatnero \\
\hline chiquillería & psiviaflelia & chiquilelría & cihquillería & chiquilabría & cufquillería \\
\hline ignorante & iudoconte & ignornate & ignroante & ignorcite & ignmaante \\
\hline sartenazo & mortirazo & sarteanzo & saretnazo & sarteorzo & sarulnazo \\
\hline servidor & saslidor & servdior & srevidor & servloor & scavidor \\
\hline ayudante & airbinte & ayudnate & auydante & ayudcite & aeqdante \\
\hline diseñador & mimivador & diseñdaor & disñeador & diseñteor & disxoador \\
\hline madrugador & bachubadar & madrugdaor & madurgador & madrugteor & madesgador \\
\hline ventilador & bontecador & ventildaor & ventliador & ventilteor & venttaador \\
\hline investigador & inlurtisadar & investigdaor & investgiador & investigteor & investpoador \\
\hline ligamento & bipalenta & ligmaento & lgiamento & ligroento & lpoamento \\
\hline paseante & maciunte & pasenate & paesante & pasecite & paurante \\
\hline aplastante & adhextonte & aplastnate & apalstante & aplastcite & apidstante \\
\hline feminismo & veserismo & femiinsmo & feimnismo & femiersmo & feunnismo \\
\hline congresista & conchedarta & congreissta & congersista & congreacsta & conginsista \\
\hline observatorio & occensatoria & observtaorio & obsrevatorio & observdoorio & obscavatorio \\
\hline temerario & beselaria & temearrio & teemrario & temeonrio & teirrario \\
\hline bajura & tafuro & baujra & bjaura & baoqra & bgeura \\
\hline modernismo & mopanlismo & moderinsmo & modrenismo & moderersmo & modcanismo \\
\hline diccionario & diudierario & diccioanrio & diciconario & diccioorrio & dicenonario \\
\hline hombretón & fempleton & hombreótn & hombertón & hombreédn & hombintón \\
\hline determinante & depenjirinte & determinnate & determniante & determincite & determceante \\
\hline tacañería & taleholia & tacaeñría & taacñería & tacaovría & taisñería \\
\hline emigrante & ecefrinte & emigrnate & emgirante & emigrcite & emporante \\
\hline acelerón & amilerad & aceleórn & aceelrón & aceleánn & aceabrón \\
\hline cornudo & calfudo & corundo & cronudo & corzodo & cmanudo \\
\hline traficante & frabelante & traficnate & trafciante & traficcite & trafnaante \\
\hline futbolista & hobmolista & futboilsta & futoblista & futboatsta & fututlista \\
\hline pegajoso & mefahoto & pegaojso & peagjoso & pegaupso & peopjoso \\
\hline curandero & cumistero & curanedro & curnadero & curanotro & curcidero \\
\hline gruñón & bruvon & gruóñn & gurñón & gruúxn & gesñón \\
\hline mediador & sevoidor & medidaor & meidador & mediteor & mealador \\
\hline criador & flaudor & cridaor & cirador & criteor & cemador \\
\hline mechón & pebron & mecóhn & mcehón & mecébn & mnihón \\
\hline sesentón & meranton & sesenótn & sesnetón & sesenédn & sesmitón \\
\hline comunicador & colutitadad & comunicdaor & comnuicador & comunicteor & comzoicador \\
\hline carterista & cosmirista & carteirsta & caretrista & carteemsta & carulrista \\
\hline fundamento & birdadento & fundmaento & fnudamento & fundroento & fzodamento \\
\hline anonimato & alicilago & anoniamto & anoinmato & anoniosto & anoermato \\
\hline huesudo & faumudo & hueusdo & huseudo & hueomdo & hunoudo \\
\hline
\end{tabular}


Table 3 (continued)

\begin{tabular}{|c|c|c|c|c|c|}
\hline $\begin{array}{l}\text { TARGET } \\
\text { WORD }\end{array}$ & $\begin{array}{l}\text { TARGET } \\
\text { NONWORD }\end{array}$ & $\begin{array}{l}\text { TL BETWEEN } \\
\text { MORPHEMES }\end{array}$ & $\begin{array}{l}\text { TL WITHIN } \\
\text { MORPHEME }\end{array}$ & $\begin{array}{l}\text { RL BETWEEN } \\
\text { MORPHEMES }\end{array}$ & $\begin{array}{l}\text { RL WITHIN } \\
\text { MORPHEME }\end{array}$ \\
\hline secretario & meflinario & secreatrio & secertario & secreilrio & secintario \\
\hline cargante & canrente & cargnate & cragante & cargcite & ccogante \\
\hline millonario & pibrolaria & milloanrio & milolnario & milloorrio & miladnario \\
\hline feminista & beserista & femiinsta & feimnista & femiersta & feunnista \\
\hline picadero & mivacera & picdaero & pciadero & picteero & pnaadero \\
\hline liderazgo & fidiralzo & lidearzgo & ldierazgo & lideonzgo & lloerazgo \\
\hline dirigente & mimebente & dirignete & dirgiente & dirigmite & dirpoente \\
\hline vigilante & bibecante & vigilnate & vigliante & vigilcite & vigtaante \\
\hline celibato & cemigaza & celiabto & ceilbato & celielto & ceatbato \\
\hline escudería & inlunenia & escuedría & esucdería & escuotría & esizdería \\
\hline soñador & rofidor & soñdaor & sñoador & soñteor & svaador \\
\hline temeroso & besiroto & temeorso & teemroso & temeanso & teirroso \\
\hline goleador & bomiadar & goledaor & goelador & goleteor & goabador \\
\hline generador & necinador & generdaor & genreador & generteor & gencaador \\
\hline canoso & cadola & caonso & cnaoso & caarso & ccioso \\
\hline comedero & corimera & comdeero & cmoedero & comtoero & csiedero \\
\hline azucarero & agufamora & azucaerro & azcuarero & azucainro & azsoarero \\
\hline moderador & pofinador & moderdaor & modreador & moderteor & modcaador \\
\hline surtidor & dirtador & surtdior & srutidor & surtloor & svetidor \\
\hline sujetador & puhinador & sujetdaor & suejtador & sujetteor & suiptador \\
\hline colador & celeror & coldaor & cloador & colteor & cdiador \\
\hline educador & amugadar & educdaor & edcuador & educteor & edsoador \\
\hline detonante & remocinte & detonnate & detnoante & detoncite & detseante \\
\hline colaborador & cotafenadar & colabordaor & colabroador & colaborteor & colabmaador \\
\hline gobernante & bofisnante & gobernnate & gobrenante & goberncite & gobcanante \\
\hline aspirador & ambenador & aspirdaor & aspriador & aspirteor & aspsoador \\
\hline latigazo & batepago & latiagzo & laitgazo & latiopzo & laafgazo \\
\hline mostrador & suntrador & mostrdaor & msotrador & mostrteor & mcutrador \\
\hline paracaidismo & sageciadisto & paracaiidsmo & parcaaidismo & paracaialsmo & parreaidismo \\
\hline esbeltez & esvaptez & esbeletz & esbletez & esbelulz & esbtitez \\
\hline exquisitez & erliasitaz & exquisietz & exquiistez & exquisiulz & exquiactez \\
\hline granero & claceno & graenro & garnero & graicro & gonnero \\
\hline operador & omidadar & operdaor & opreador & operteor & opcaador \\
\hline secuestrador & metiantrador & secuestrdaor & secusetrador & secuestrteor & secunotrador \\
\hline pistoletazo & sontoretalo & pistoleatzo & pistloetazo & pistoleilzo & pistdietazo \\
\hline ajedrecista & agirrocisma & ajedreicsta & ajedercista & ajedreensta & ajedincista \\
\hline cincuentón & cenduinton & cincuenótn & cincunetón & cincuenédn & cincumitón \\
\hline solicitante & pinaritante & solicitnate & solictiante & solicitcite & solicleante \\
\hline jugador & zudidor & jugdaor & jguador & jugteor & jpiador \\
\hline repelente & pefirente & repelnete & repleente & repelmite & reptiente \\
\hline secador & tevidor & secdaor & sceador & secteor & sniador \\
\hline torero & nodeto & toerro & troero & toinro & tmaero \\
\hline cuarentón & celventon & cuarenótn & cuaerntón & cuarenédn & cuainntón \\
\hline criadero & freupero & cridaero & ciradero & criteero & cemadero \\
\hline blancura & clindura & blanucra & balncura & blanizra & bidncura \\
\hline gritón & lleton & griótn & girtón & griédn & gemtón \\
\hline purgante & mulbante & purgnate & prugante & purgcite & pvegante \\
\hline oratorio & omasonia & ortaorio & oartorio & ordoorio & oontorio \\
\hline
\end{tabular}


Table 3 (continued)

\begin{tabular}{|c|c|c|c|c|c|}
\hline $\begin{array}{l}\text { TARGET } \\
\text { WORD }\end{array}$ & $\begin{array}{l}\text { TARGET } \\
\text { NONWORD }\end{array}$ & $\begin{array}{l}\text { TL BETWEEN } \\
\text { MORPHEMES }\end{array}$ & $\begin{array}{l}\text { TL WITHIN } \\
\text { MORPHEME }\end{array}$ & $\begin{array}{l}\text { RL BETWEEN } \\
\text { MORPHEMES }\end{array}$ & $\begin{array}{l}\text { RL WITHIN } \\
\text { MORPHEME }\end{array}$ \\
\hline rigidez & sigidid & rigiedz & riigdez & rigiotz & riepdez \\
\hline encendedor & enmarfedor & encenddeor & enecndedor & encendtoor & enasndedor \\
\hline archivador & ancrebador & archivdaor & archviador & archivteor & archzaador \\
\hline domador & soridor & domdaor & dmoador & domteor & dsiador \\
\hline veraneante & tegeceinte & veranenate & veraenante & veranecite & veraicante \\
\hline protestante & promartonte & protestnate & protsetante & protestcite & protnotante \\
\hline asaltante & amirnante & asaltnate & aslatante & asaltcite & asdotante \\
\hline panadero & macasera & panaedro & pnaadero & panaotro & pciadero \\
\hline violinista & buelelista & violiinsta & vioilnista & violiersta & vioatnista \\
\hline salvamento & mosvadento & salvmaento & slavamento & salvroento & sdovamento \\
\hline zapatería & naminelia & zapaetría & zpaatería & zapaulría & zgoatería \\
\hline cenicero & cemelera & ceniecro & ceincero & ceniasro & ceercero \\
\hline debutante & remudinte & debutnate & deubtante & debutcite & deodtante \\
\hline cocinero & corecera & cocienro & coicnero & cociicro & coennero \\
\hline justificante & nortivicunte & justificnate & justifciante & justificcite & justifnaante \\
\hline estudiante & enmusuente & estudinate & estduiante & estudicite & estfoiante \\
\hline emisario & esedaria & emiasrio & eimsario & emiecrio & eunsario \\
\hline amigdalitis & amabsalizos & amigdailtis & amigadlitis & amigdaattis & amigollitis \\
\hline viajante & veifente & viajnate & vijaante & viajcite & vigeante \\
\hline comedor & ceceror & comdeor & cmoedor & comtoor & csiedor \\
\hline coordinador & coesliradar & coordindaor & coordniador & coordinteor & coordceador \\
\hline participante & mextinivante & participnate & particpiante & participcite & particguante \\
\hline palidez & malidid & paliedz & paildez & paliotz & paatdez \\
\hline agitador & amacadar & agitdaor & agtiador & agitteor & agleador \\
\hline pistolero & mimpocero & pistoelro & pisotlero & pistoabro & pisedlero \\
\hline pluralismo & brunanisto & plurailsmo & pulralismo & pluraatsmo & petralismo \\
\hline merecedor & pecitedor & merecdeor & merceedor & merectoor & merniedor \\
\hline albañilería & armosilinia & albañielría & albaiñlería & albañiabría & albaehlería \\
\hline humillante & bunegrante & humillnate & humlilante & humillcite & humtalante \\
\hline pesimismo & pecedisto & pesiimsmo & peismismo & pesiunsmo & peacmismo \\
\hline zapatazo & wasanalo & zapaatzo & zaaptazo & zapailzo & zaegtazo \\
\hline humanista & bumalarta & humainsta & huamnista & humaersta & huosnista \\
\hline monetario & mosinaria & moneatrio & moentario & moneilrio & moictario \\
\hline colorista & cocorensa & coloirsta & coolrista & coloemsta & coadrista \\
\hline alcoholismo & artoñoristo & alcohoilsmo & alcoohlismo & alcohoatsmo & alcoeblismo \\
\hline tapicería & tacarolia & tapiecría & taipcería & tapiasría & taejcería \\
\hline comerciante & cosanriante & comercinate & comreciante & comercicite & comcaciante \\
\hline tendedero & foncidero & tenddeero & tnededero & tendtoero & tmidedero \\
\hline ebanista & emanarna & ebainsta & eabnista & ebaersta & eelnista \\
\hline borrador & tollidor & borrdaor & brorador & borrteor & bmarador \\
\hline papelón & pavelal & papeóln & paeplón & papeádn & paiglón \\
\hline ciclista & cifrinda & cicilsta & ccilista & cicatsta & cnalista \\
\hline escudero & enmumera & escuedro & esucdero & escuotro & esizdero \\
\hline entrenador & esgricador & entrendaor & entrneador & entrenteor & entrmiador \\
\hline velatorio & benaroria & veltaorio & vleatorio & veldoorio & vtiatorio \\
\hline contestador & consacdador & contestdaor & contsetador & contestteor & contnotador \\
\hline florero & clodeto & floerro & folrero & floinro & fadrero \\
\hline militante & mimerinte & militnate & miltiante & militcite & milleante \\
\hline
\end{tabular}


Table 3 (continued)

\begin{tabular}{|c|c|c|c|c|c|}
\hline $\begin{array}{l}\text { TARGET } \\
\text { WORD }\end{array}$ & $\begin{array}{l}\text { TARGET } \\
\text { NONWORD }\end{array}$ & $\begin{array}{l}\text { TL BETWEEN } \\
\text { MORPHEMES }\end{array}$ & $\begin{array}{l}\text { TL WITHIN } \\
\text { MORPHEME }\end{array}$ & $\begin{array}{l}\text { RL BETWEEN } \\
\text { MORPHEMES }\end{array}$ & $\begin{array}{l}\text { RL WITHIN } \\
\text { MORPHEME }\end{array}$ \\
\hline arenoso & aniroto & areonso & aernoso & arearso & ainnoso \\
\hline fumadero & burasera & fumdaero & fmuadero & fumteero & fñaadero \\
\hline pensador & panvidor & pensdaor & pnesador & pensteor & pmisador \\
\hline solidez & rolidid & soliedz & soildez & soliotz & soatdez \\
\hline fregadero & premamera & fregdaero & frgeadero & fregteero & frjaadero \\
\hline clasista & blacusta & claissta & calsista & claacsta & cidsista \\
\hline velocista & becodisto & veloicsta & veolcista & veloensta & veadcista \\
\hline cobrador & ceflaror & cobrdaor & cborador & cobrteor & cfarador \\
\hline cabezón & cadezal & cabeózn & caebzón & cabeáxn & caofzón \\
\hline escasez & esciced & escaesz & esacsez & escaurz & esissez \\
\hline congelador & comnitador & congeldaor & cnogelador & congelteor & csegelador \\
\hline insultante & inmoznante & insultnate & inslutante & insultcite & insbetante \\
\hline hermosura & vaslosura & hermousra & heromsura & hermoomra & herussura \\
\hline hospitalario & tunditalaria & hospitaalrio & hosiptalario & hospitaidrio & hosejtalario \\
\hline cristalería & psimbarelia & cristaelría & crsitalería & cristaabría & crmotalería \\
\hline mandatario & monvanaria & mandaatrio & manadtario & mandailrio & manoltario \\
\hline sanatorio & maraloria & santaorio & snaatorio & sandoorio & sciatorio \\
\hline amortiguador & amistiferdor & amortigudaor & amoritguador & amortiguteor & amorafguador \\
\hline boxeador & bungiador & boxedaor & boexador & boxeteor & boazador \\
\hline gobernador & godanrador & goberndaor & goebrnador & gobernteor & goofrnador \\
\hline estimulante & esmacuninte & estimulnate & estimluante & estimulcite & estimbeante \\
\hline competidor & cadmitidor & competdior & comeptidor & competloor & comigtidor \\
\hline letrero & necrera & leterro & lterero & letinro & ldarero \\
\hline gelatinoso & tetacirozo & gelationso & gelaitnoso & gelatiarso & gelaafnoso \\
\hline madrugón & paclumon & madruógn & madurgón & madruápn & madesgón \\
\hline veraniego & benaneifo & verainego & vearniego & veraerego & veonniego \\
\hline originario & ogafiraria & origianrio & oriignario & origiorrio & oriepnario \\
\hline nadador & favidor & naddaor & ndaador & nadteor & nteador \\
\hline montañoso & pintazoto & montaoñso & mnotañoso & montauxso & msetañoso \\
\hline deportista & remirtisto & deporitsta & deoprtista & deporafsta & deagrtista \\
\hline enfermería & enlorcolia & enferemría & enefrmería & enferirría & enahrmería \\
\hline calmante & carcente & calmnate & camlante & calmcite & cankante \\
\hline paliducho & safitudro & paliudcho & pailducho & paliifcho & paatducho \\
\hline herrero & nelleto & hererro & hrerero & herinro & hcarero \\
\hline vaporoso & bavonoto & vapoorso & vaoproso & vapoanso & vaagroso \\
\hline elitista & amatilta & eliitsta & eiltista & eliafsta & eattista \\
\hline guerrero & neuflero & guererro & gurerero & guerinro & gucarero \\
\hline cargamento & cosmacento & cargmaento & cragamento & cargroento & ccogamento \\
\hline frutero & grucera & fruetro & furtero & fruulro & festero \\
\hline refranero & petlalera & refraenro & refarnero & refraicro & refonnero \\
\hline cafetería & dagecolia & cafeetría & caeftería & cafeulría & caahtería \\
\hline bancario & bartaria & banacrio & bnacario & banisrio & bcicario \\
\hline negociador & gevotiodor & negocidaor & neogciador & negociteor & neapciador \\
\hline patrullero & marruprera & patrulelro & paturllero & patrulabro & patesllero \\
\hline tendero & bincero & tenedro & tnedero & tenotro & tmidero \\
\hline misionero & riciarero & misioenro & miisonero & misioicro & miaconero \\
\hline integrante & incifrunte & integrnate & inetgrante & integrcite & inulgrante \\
\hline vocabulario & tolefurario & vocabualrio & voacbulario & vocabuidrio & voisbulario \\
\hline
\end{tabular}


Table 3 (continued)

\begin{tabular}{|c|c|c|c|c|c|}
\hline $\begin{array}{l}\text { TARGET } \\
\text { WORD }\end{array}$ & $\begin{array}{l}\text { TARGET } \\
\text { NONWORD }\end{array}$ & $\begin{array}{l}\text { TL BETWEEN } \\
\text { MORPHEMES }\end{array}$ & $\begin{array}{l}\text { TL WITHIN } \\
\text { MORPHEME }\end{array}$ & $\begin{array}{l}\text { RL BETWEEN } \\
\text { MORPHEMES }\end{array}$ & $\begin{array}{l}\text { RL WITHIN } \\
\text { MORPHEME }\end{array}$ \\
\hline probador & trodidor & probdaor & prboador & probteor & prfaador \\
\hline gravedad & clabedaz & gravdead & grvaedad & gravtoad & grñoedad \\
\hline caluroso & camutova & caluorso & caulroso & caluanso & caetroso \\
\hline purgatorio & pizpalorio & purgtaorio & prugatorio & purgdoorio & pvegatorio \\
\hline martillazo & mortefravo & martilalzo & mratillazo & martilidzo & mcotillazo \\
\hline concursante & condaldante & concursnate & concrusante & concurscite & concvesante \\
\hline petrolero & meflodera & petroelro & petorlero & petroabro & petanlero \\
\hline repetidor & bafitidor & repetdior & reeptidor & repetloor & reigtidor \\
\hline preparador & pramadadar & prepardaor & preaprador & preparteor & preegrador \\
\hline pacifista & mamebista & paciifsta & paicfista & paciudsta & paenfista \\
\hline limonero & birorera & limoenro & liomnero & limoicro & liusnero \\
\hline guitarrista & boicadrista & guitarirsta & guitrarista & guitaremsta & guitcorista \\
\hline triunfador & trensfidor & triunfdaor & trinufador & triunfteor & trizofador \\
\hline pacifismo & masiñisto & paciifsmo & paicfismo & paciudsmo & paenfismo \\
\hline orador & icaror & ordaor & oardor & orteor & oondor \\
\hline cubertería & duborlolia & cuberetría & cuebrtería & cuberulría & cuofrtería \\
\hline cervecería & dombeneria & cerveecría & cerevcería & cerveasría & ceruñcería \\
\hline secundario & merincario & secunadrio & secnudario & secunolrio & seczodario \\
\hline cargador & calpidor & cargdaor & cragador & cargteor & ccogador \\
\hline moralista & momalensa & morailsta & moarlista & moraatsta & moonlista \\
\hline sencillez & sensalled & sencilelz & senicllez & sencilabz & senenllez \\
\hline apeadero & aleamoca & apedaero & aepadero & apeteero & aigadero \\
\hline camionero & cacuerera & camioenro & cmaionero & camioicro & croionero \\
\hline lugareño & buvanefo & lugaerño & lguareño & lugainño & lpiareño \\
\hline espejismo & espefanco & espeijsmo & esepjismo & espeugsmo & esigjismo \\
\hline papelería & satarelia & papeelría & paeplería & papeabría & paiglería \\
\hline barrigudo & vatrepudo & barriugdo & barirgudo & barriijdo & baremgudo \\
\hline pesimista & seredista & pesiimsta & peismista & pesiunsta & peacmista \\
\hline prisionero & primailera & prisioenro & pirsionero & prisioicro & pemsionero \\
\hline comprador & cosclidor & comprdaor & cmoprador & comprteor & csiprador \\
\hline animador & amabadar & animdaor & ainmador & animteor & aermador \\
\hline absolutismo & anlirutisto & absoluitsmo & absoultismo & absoluafsmo & absoettismo \\
\hline colgante & cobsente & colgnate & clogante & colgcite & cdigante \\
\hline progresista & proflisarta & progreissta & progersista & progreacsta & proginsista \\
\hline remolcador & resadmador & remolcdaor & remlocador & remolcteor & remdicador \\
\hline admirador & azpenador & admirdaor & adimrador & admirteor & adunrador \\
\hline gigantón & fipenton & giganótn & giagntón & giganédn & giopntón \\
\hline calculador & cosfurador & calculdaor & calcluador & calculteor & calcbeador \\
\hline delineante & detacointe & delinenate & delnieante & delinecite & delceeante \\
\hline acomodador & alocedadad & acomoddaor & acomdoador & acomodteor & acomlaador \\
\hline borrón & lollon & borórn & brorón & boránn & bmarón \\
\hline decorador & demetadar & decordaor & decroador & decorteor & decmaador \\
\hline negociante & gevolionte & negocinate & negoicante & negocicite & negoenante \\
\hline tesorería & lerocolia & tesoerría & teosrería & tesoinría & teamrería \\
\hline jardinero & janvetero & jardienro & jaridnero & jardiicro & jaralnero \\
\hline llevadero & frehalera & llevdaero & llveadero & llevteero & llruadero \\
\hline chillón & trirron & chilóln & chlilón & chiládn & chtalón \\
\hline cacería & caticio & caecría & ccaería & caasría & creería \\
\hline
\end{tabular}


Table 3 (continued)

\begin{tabular}{|c|c|c|c|c|c|}
\hline $\begin{array}{l}\text { TARGET } \\
\text { WORD }\end{array}$ & $\begin{array}{l}\text { TARGET } \\
\text { NONWORD }\end{array}$ & $\begin{array}{l}\text { TL BETWEEN } \\
\text { MORPHEMES }\end{array}$ & $\begin{array}{l}\text { TL WITHIN } \\
\text { MORPHEME }\end{array}$ & $\begin{array}{l}\text { RL BETWEEN } \\
\text { MORPHEMES }\end{array}$ & $\begin{array}{l}\text { RL WITHIN } \\
\text { MORPHEME }\end{array}$ \\
\hline contestón & cancecton & contesótn & cnotestón & contesédn & csetestón \\
\hline exportador & ernectador & exportdaor & exprotador & exportteor & expmatador \\
\hline telefonista & tecaselista & telefoinsta & teleofnista & telefoersta & teleebnista \\
\hline realizador & teecipadar & realizdaor & reailzador & realizteor & reaatzador \\
\hline consumidor & calmusidor & consumdior & consmuidor & consumloor & consñaidor \\
\hline espinoso & escecoto & espionso & esipnoso & espiarso & esejnoso \\
\hline faringitis & banispitis & farinigtis & farnigitis & farineptis & farcegitis \\
\hline interrogante & incallegunte & interrognate & intrerogante & interrogcite & intcarogante \\
\hline optimista & osmidisca & optiimsta & opitmista & optiunsta & opafmista \\
\hline sillón & rirron & silóln & slilón & siládn & stalón \\
\hline recordatorio & retescatoria & recordtaorio & recrodatorio & recorddoorio & recmadatorio \\
\hline proveedor & profiodar & provedeor & proevedor & provetoor & prouñedor \\
\hline votante & tocente & votnate & vtoante & votcite & vdeante \\
\hline maletero & macilera & maleetro & maeltero & maleulro & maabtero \\
\hline relojería & telibolia & reloejría & reoljería & reloipría & readjería \\
\hline guardería & nansleria & guaredría & guradería & guarotría & gucodería \\
\hline oxidante & olzemante & oxidnate & oxdiante & oxidcite & oxloante \\
\hline volador & loridor & voldaor & vloador & volteor & vdiador \\
\hline aceitoso & amoicoto & aceiotso & aecitoso & aceiedso & aasitoso \\
\hline consejero & conmihera & conseejro & cnosejero & conseipro & csesejero \\
\hline absolutista & anlarutisma & absoluitsta & absoultista & absoluafsta & absoettista \\
\hline 1lorón & flolon & lloórn & lolrón & lloánn & ladrón \\
\hline imitador & omasadar & imitdaor & imtiador & imitteor & imleador \\
\hline apendicitis & atorbicimis & apendiictis & apenidcitis & apendientis & apenalcitis \\
\hline picotazo & rimonalo & picoatzo & pioctazo & picoilzo & piivtazo \\
\hline especulador & estanumadar & especuldaor & espeuclador & especulteor & espeizlador \\
\hline practicante & priltelante & practicnate & pracitcante & practiccite & pracafcante \\
\hline picajoso & mimahoto & picaojso & piacjoso & picaupso & piisjoso \\
\hline portería & mostinia & poretría & protería & porulría & pmatería \\
\hline simplón & silclon & simpóln & smiplón & simpádn & sneplón \\
\hline conquistador & conmoiorador & conquistdaor & cnoquistador & conquistteor & csequistador \\
\hline sensatez & sancitez & sensaetz & senastez & sensaulz & senectez \\
\hline timbrazo & timpligo & timbarzo & tmibrazo & timbonzo & tnebrazo \\
\hline cabezudo & camifuda & cabeuzdo & caebzudo & cabeoxdo & caofzudo \\
\hline observador & osmanvador & observdaor & obesrvador & observteor & oburrvador \\
\hline optimismo & obtedisto & optiimsmo & opitmismo & optiunsmo & opafmismo \\
\hline pastelero & mantirero & pasteelro & pasetlero & pasteabro & pasullero \\
\hline amargura & acespura & amarugra & amragura & amarijra & amcogura \\
\hline tontorrón & bintoblon & tontorórn & tnotorrón & tontoránn & tsetorrón \\
\hline coladero & dimadoro & coldaero & cloadero & colteero & cdiadero \\
\hline lanzador & vinjador & lanzdaor & lnazador & lanzteor & lcizador \\
\hline basurero & vamucera & basuerro & bausrero & basuinro & baomrero \\
\hline vendedor & finsedor & venddeor & vnededor & vendtoor & vmidedor \\
\hline tolerante & bomirinte & tolernate & toelrante & tolercite & toabrante \\
\hline cuidador & ciapidor & cuiddaor & cudiador & cuidteor & culoador \\
\hline futbolero & hapsolero & futboelro & futoblero & futboabro & fututlero \\
\hline fundador & fuspidor & funddaor & fnudador & fundteor & fzodador \\
\hline terrorista & beflonisca & terroirsta & trerorista & terroemsta & tcarorista \\
\hline
\end{tabular}


Table 3 (continued)

\begin{tabular}{|c|c|c|c|c|c|}
\hline $\begin{array}{l}\text { TARGET } \\
\text { WORD }\end{array}$ & $\begin{array}{l}\text { TARGET } \\
\text { NONWORD }\end{array}$ & $\begin{array}{l}\text { TL BETWEEN } \\
\text { MORPHEMES }\end{array}$ & $\begin{array}{l}\text { TL WITHIN } \\
\text { MORPHEME }\end{array}$ & $\begin{array}{l}\text { RL BETWEEN } \\
\text { MORPHEMES }\end{array}$ & $\begin{array}{l}\text { RL WITHIN } \\
\text { MORPHEME }\end{array}$ \\
\hline caminante & cacecinte & caminnate & caimnante & camincite & caunnante \\
\hline humorista & bumonarta & humoirsta & huomrista & humoemsta & huusrista \\
\hline monedero & pomimero & moneedro & moendero & moneotro & moicdero \\
\hline principiante & prindevuente & principinate & prinicpiante & principicite & prinenpiante \\
\hline cabelludo & camifruda & cabeluldo & caeblludo & cabeletdo & caoflludo \\
\hline patrocinador & safroniradar & patrocindaor & patroicnador & patrocinteor & patroennador \\
\hline pensionista & monfianista & pensioinsta & penisonista & pensioersta & penaconista \\
\hline laboratorio & tagoracocie & labortaorio & labroatorio & labordoorio & labmaatorio \\
\hline relojero & pemobera & reloejro & reoljero & reloipro & readjero \\
\hline destilería & desmarolia & destielría & desitlería & destiabría & desaflería \\
\hline navegante & bapipante & navegnate & naevgante & navegcite & nauñgante \\
\hline acogedor & amibodor & acogdeor & aocgedor & acogtoor & aivgedor \\
\hline librería & biflinia & liberría & lbirería & libinría & lharería \\
\hline trabajador & pramasadar & trabajdaor & trabjaador & trabajteor & trabgeador \\
\hline salvador & sarfidor & salvdaor & slavador & salvteor & sdovador \\
\hline emprendedor & erplercedor & emprenddeor & emprnededor & emprendtoor & emprmidedor \\
\hline bromista & clodasta & broimsta & bormista & brounsta & banmista \\
\hline algodonoso & anhosolozo & algodoonso & alogdonoso & algodoarso & alapdonoso \\
\hline tesorero & becocera & tesoerro & teosrero & tesoinro & teamrero \\
\hline afilador & amesadar & afildaor & afliador & afilteor & aftaador \\
\hline respiratorio & teslecacorio & respirtaorio & respriatorio & respirdoorio & respsoatorio \\
\hline medidor & pevador & meddior & mdeidor & medloor & mtoidor \\
\hline vistoso & tustoco & visotso & vsitoso & visedso & vmotoso \\
\hline amplificador & ancragicadar & amplificdaor & ampilficador & amplificteor & ampatficador \\
\hline contenedor & coscicedor & contendeor & conetnedor & contentoor & conulnedor \\
\hline
\end{tabular}

TL, transposed letters; RL, replaced letters

\section{Appendix B: Regression analyses}

We examined whether some critical properties of polymorphemic words could have covaried with the magnitude of the between-morpheme and within-morpheme TL effects for each of the two groups (i.e., faster and slower participants). To this end, we computed the magnitude of the TL effect (replaced-letter condition minus transposed-letter condition) for the averaged responses to each individual word separately for each group and place of manipulation. Given that the materials were selected to ensure (1) a sufficient degree of generalization of the results to the item population $(n=420)$, and (2) adequate representativeness of the heterogeneity of each individual factor explored (see the ranges and $S D$ s presented in Table 1), it can be confidently expected that if any of the factors under investigation were directly responsible for the modulation of the magnitude of the TL effects, on top of the speed and strategy of response of the participants (and the cognitive processes associated with this speed), such a result would emerge in these regression analyses.
The factors included in the regression models were Word, Base, and Suffix Length (e.g., the numbers of letters in "violinista," "violín," and "ista"), the Frequency of the words and bases and their Orthographic Neighborhood Sizes, the Levenshtein Distance between the base and the stem (the number of edits needed so that the string corresponding to the base would exactly match the string corresponding to the stem; see Yarkoni, Balota, \& Yap, 2008), the Morphological Family Size of the bases and the suffixes (individually computed for each item, considering the lexicon included in B-Pal and the SCOGEME morphological management computational system for Spanish developed at the ULPGC), the Cumulative Frequency of the morphological family of the bases and suffixes (see Ford, Marslen-Wilson, \& Davis, 2003), and the Frequency of the Bigrams constituting the morphemic boundary (e.g., the frequency of "ni" in "violinista"; see the bigram trough hypothesis proposed by Seidenberg, 1989).

The results of the regression analyses were clear cut. With the exception of the regression model of the between- 
morphemes TL effects for the faster participants $(p=.04)$ (see the Supplementary Table), none of the other models reached significance $(p s>.50)$. The model fitted to the betweenmorpheme TL effect for the faster participants showed that the base word frequency and orthographic neighborhood of the whole word accounted for a significant portion of the variance (both $p \mathrm{~s}=.04$ ). Hence, the magnitude of the between-morpheme TL effects was modulated by these two lexical properties of the words in the group of faster participants.

\section{References}

Amenta, S., \& Crepaldi, D. (2012). Morphological processing as we know it: An analytical review of morphological effects in visual word identification. Frontiers in Language Sciences, 3, 232.

Andrews, S., \& Lo, S. (2013). Is morphological priming stronger for transparent than opaque words? It depends on individual differences in spelling and vocabulary. Journal of Memory and Language, 68, 279-296.

Balota, D. A., Yap, M. J., Cortese, M. J., \& Watson, J. M. (2008). Beyond mean response latency: Response time distributional analyses of semantic priming. Journal of Memory and Language, 59, 495523. doi:10.1016/j.jml.2007.10.004

Beyersmann, E., Coltheart, M., \& Castles, A. (2012). Parallel processing of whole words and morphemes in visual word recognition. Quarterly Journal of Experimental Psychology, 65, 1798-1819. doi:10.1080/17470218.2012.672437

Beyersmann, E., McCormick, S. F., \& Rastle, K. (2013). Letter transpositions within morphemes and across morpheme boundaries. Quarterly Journal of Experimental Psychology, 66, 2389-2410.

Button, K. S., Ioannidis, J. P. A., Mokrysz, C., Nosek, B. A., Flint, J., Robinson, E. S. J., \& Munafò, M. R. (2013). Power failure: Why small sample size undermines the reliability of neuroscience. Nature Reviews, 14, 365-376.

Chace, K. H., Rayner, K., \& Well, A. D. (2005). Eye movements and phonological parafoveal preview: Effects of reading skill. Canadian Journal of Experimental Psychology, 59, 209-217.

Chateau, D., \& Jared, D. (2000). Exposure to print and word recognition processes. Memory \& Cognition, 28, 143-153. doi:10.3758/ BF03211582

Christianson, K., Johnson, R. L., \& Rayner, K. (2005). Letter transpositions within and across morphemes. Journal of Experimental Psychology: Learning, Memory, and Cognition, 31, 1327-1339. doi:10.1037/0278-7393.31.6.1327

Davis, C. J., \& Perea, M. (2005). BuscaPalabras: A program for deriving orthographic and phonological neighborhood statistics and other psycholinguistic indices in Spanish. Behavior Research Methods, 37, 665-671. doi:10.3758/BF03192738

Diependaele, K., Duñabeitia, J. A., Morris, J., \& Keuleers, E. (2011). Fast morphological effects in first and second language word recognition. Journal of Memory and Language, 64, 344-358. doi:10.1016/ j.jml.2011.01.003

Diependaele, K., Morris, J., Serota, R. M., Bertrand, D., \& Grainger, J. (2013). Breaking boundaries: Letter transpositions and morphological processing. Language and Cognitive Processes, 28, 988-1003.

Diependaele, K., Sandra, D. \& Grainger, J. (2005). Masked cross-modal morphological priming: Unravelling morpho-orthographic and morphosemantic influences in early word recognition. Language and Cognitive Processes, 20, 75-114.
Duñabeitia, J. A., Perea, M., \& Carreiras, M. (2007). Do transposed-letter similarity effects occur at a morpheme level? Evidence for morphoorthographic decomposition. Cognition, 105, 691-703. doi:10. 1016/j.cognition.2006.12.001

Duñabeitia, J. A., Perea, M., \& Carreiras, M. (2008). Does darkness lead to happiness? Masked suffix priming effects. Language and Cognitive Processes, 23, 1002-1020.

Faust, M. E., Balota, D. A., Spieler, D. H., \& Ferraro, F. R. (1999). Individual differences in information processing rate and amount: Implications for group differences in response latency. Psychological Bulletin, 125, 777-799.

Ford, M., Marslen-Wilson, W. D., \& Davis, M. H. (2003). Morphology and frequency: Contrasting methodologies. In R. H. Baayen \& R. Schreuder (Eds.), Morphological structure in language processing (pp. 89-124). Berlin, Germany: Mouton de Gruyter.

Forster, K. I., \& Forster, J. C. (2003). DMDX: A Windows display program with millisecond accuracy. Behavior Research Methods, Instruments, \& Computers, 35, 116-124. doi:10.3758/BF03195503

Frankish, C., \& Barnes, L. (2008). Lexical and sublexical processes in the perception of transposed-letter anagrams. Quarterly Journal of Experimental Psychology, 61, 381-391. doi:10.1080/ 17470210701664880

Frankish, C., \& Turner, E. (2007). SIHGT and SUNOD: The role of orthography and phonology in the perception of transposed letter anagrams. Journal of Memory and Language, 56, 189-211. doi:10. 1016/j.jml.2006.11.002

Gomez, P., Ratcliff, R., \& Perea, M. (2008). The overlap model: A model of letter position coding. Psychological Review, 115, 577-600. doi: 10.1037/a0012667

Grainger, J., \& Whitney, C. (2004). Does the huamn mind raed wrods as a wlohe? Trends in Cognitive Sciences, 8, 58-59. doi:10.1016/j.tics. 2003.11.006

Häikiö, T., Bertram, R., Hyönä, J., \& Niemi, P. (2009). Development of letter identity span in reading: Evidence from the eye movement moving window paradigm. Journal of Experimental Child Psychology, 102, 167-181.

Hargreaves, I. S., Pexman, P. M., Zdrazilova, L., \& Sargious, P. (2012). How a hobby can shape cognition: Visual word recognition in competitive Scrabble players. Memory \& Cognition, 40, 1-7. doi: 10.3758/s13421-011-0137-5

Janack, J., Pastizzo, M. J., \& Feldman, L. B. (2004). When orthographic neighbors fail to facilitate. Brain and Language, 90, 441-452.

Johnson, R. L., Staub, A., \& Fleri, A. M. (2012). Distributional analysis of the transposed-letter neighborhood effect on naming latency. Journal of Experimental Psychology: Learning, Memory, and Cognition, 38, 1773-1779.

Keuleers, E., \& Brysbaert, M. (2010). Wuggy: A multilingual pseudoword generator. Behavior Research Methods, 42, 627-633. doi:10.3758/BRM.42.3.627

Keuleers, E., Diependaele, K., \& Brysbaert, M. (2010). Practice effects in large-scale visual word recognition studies: A lexical decision study on 14,000 Dutch mono- and disyllabic words and nonwords. Frontiers in Psychology, 1, 174. doi:10.3389/fpsyg.2010.00174

Lavric, A., Elchlepp, H., \& Rastle, K. (2012). Tracking hierarchical processing in morphological decomposition with brain potentials. Journal of Experimental Psychology: Human Perception and Performance, 38, 811-816.

Luke, S. G., \& Christianson, K. (2013). The influence of frequency across the time course of morphological processing: Evidence from the transposed-letter effect. Journal of Cognitive Psychology, 25, 781799. doi:10.1080/20445911.2013.832682

Masserang, K. M., \& Pollatsek, A. (2012). Transposed letter effects in prefixed words: Implications for morphological decomposition. Journal of Cognitive Psychology, 24, 476-495.

Pastizzo, M. J., \& Feldman, L. B. (2002). Discrepancies between orthographic and unrelated baselines in masked priming undermine a 
decompositional account of morphological facilitation. Journal of Experimental Psychology: Learning, Memory, and Cognition, 28, 244-249.

Pastizzo, M. J., \& Feldman, L. B. (2004). Morphological processing: A comparison between free and bound stem facilitation. Brain and Language, 90, 31-39.

Perea, M., \& Acha, J. (2009). Does letter position coding depend on consonant/vowel status? Evidence with the masked priming technique. Acta Psychologica, 130, 127-137. doi:10.1016/j.actpsy.2008.11.001

Perea, M., \& Carreiras, M. (2008). Do orthotactics and phonology constrain the transposed-letter effect? Language and Cognitive Processes, 23, 69-92. doi:10.1080/01690960701578146

Perea, M., \& Lupker, S. J. (2003). Transposed-letter confusability effects in masked form priming. In S. Kinoshita \& S. J. Lupker (Eds.), Masked priming: State of the art (pp. 97-120). Hove, UK: Psychology Press.

Perfetti, C. A. (2007). Reading ability: Lexical quality to comprehension. Scientific Studies of Reading, 11, 357-383.

Perfetti, C. A., \& Hart, L. (2001). The lexical bases of comprehension skill. In D. S. Gorfein (Ed.), On the consequences of meaning selection: Perspectives on resolving lexical ambiguity (pp. 67-86). Washington, DC: American Psychological Association.

Pollatsek, A., \& Well, A. (1995). On the use of counterbalanced designs in cognitive research: A suggestion for a better and more powerful analysis. Journal of Experimental Psychology: Learning, Memory, and Cognition, 21, 785-794. doi:10.1037/0278-7393.21.3.785

Rastle, K., Davis, M. H., \& New, B. (2004). The broth in my brother's brothel: Morpho-orthographic segmentation in visual word recognition. Psychonomic Bulletin \& Review, 11, 1090-1098. doi:10.3758/ BF03196742

Ratcliff, R. (1979). Group reaction time distributions and an analysis of distribution statistics. Psychological Bulletin, 86, 446-461. doi:10. 1037/0033-2909.86.3.446

Rayner, K., Slattery, T. J., \& Bélanger, N. N. (2010). Eye movements, the perceptual span, and reading speed. Psychonomic Bulletin \& Review, 17, 834-839. doi:10.3758/PBR.17.6.834
Rueckl, J. G., \& Rimzhim, A. (2011). On the interaction of letter transpositions and morphemic boundaries. Language and Cognitive Processes, 26, 482-508. doi:10.1080/01690965.2010.500020

Sánchez-Gutiérrez, C., \& Rastle, K. (2013). Letter transpositions within and across morphemic boundaries: Is there a crosslanguage difference? Psychonomic Bulletin \& Review, 20, 988-996.

Seidenberg, M. S. (1989). Reading complex words. In G. N. Carlson \& M. K. Tanenhaus (Eds.), Linguistic structure in language processing (pp. 53-105). Dordrecht, The Netherlands: Kluwer.

Stanovich, K. E., \& West, R. F. (1989). Exposure to print and orthographic processing. Reading Research Quarterly, 24, 402433.

Taft, M., \& Forster, K. I. (1975). Lexical storage and retrieval of prefixed words. Journal of Verbal Learning and Verbal Behavior, 14, 638647. doi:10.1016/S0022-5371(75)80051-X

Taft, M., \& Forster, K. I. (1976). Lexical storage and retrieval of polymorphemic and polysyllabic words. Journal of Verbal Learning and Verbal Behavior, 15, 607-620.

Taft, M., \& Nillsen, C. (2013). Morphological decomposition and the transposed-letter (TL) position effect. Language and Cognitive Processes, 28, 917-938.

Unsworth, S. J., \& Pexman, P. M. (2003). The impact of reader skill on phonological processing in visual word recognition. Quarterly Journal of Experimental Psychology, 56A, 63-81.

Yap, M. J., Tse, C. S., \& Balota, D. A. (2009). Individual differences in the joint effects of semantic priming and word frequency: The role of lexical integrity. Journal of Memory and Language, 61, 303. doi: 10.1016/j.jml.2009.07.001

Yarkoni, T., Balota, D., \& Yap, M. (2008). Moving beyond Coltheart's $N$ : A new measure of orthographic similarity. Psychonomic Bulletin \& Review, 15, 971-979. doi:10.3758/PBR.15.5.971

Ziegler, J. C., Jacobs, A. M., \& Klüppel, D. (2001). Pseudohomophone effects in lexical decision: Still a challenge for current models of word recognition. Journal of Experimental Psychology: Human Perception and Performance, 27, 547-559. 